\title{
Recycling pulp mill sludge to improve soil fertility using GIS tools
}

\author{
Paulo Ribeiro a , António Albuquerque ${ }^{\mathrm{a}, *}$, Luis Quinta-Nova ${ }^{\mathrm{b}}$, Victor Cavaleiro ${ }^{\mathrm{a}}$ \\ a Department of Civil Engineering and Architecture, University of Beira Interior, Edificio 2 das Engenharias, Calcada Fonte do Lameiro, 6201-001 Covilha, Portugal \\ ${ }^{\mathrm{b}}$ Escola Superior Agrária, Polytechnic Institute of Castelo Branco, Quinta da Senhora de Mércules, Apartado 119, 6001-909 Castelo Branco, Portugal
}

\section{A R T I C L E I N F O}

\section{Article history:}

Received 26 November 2009

Received in revised form 9 May 2010

Accepted 15 May 2010

\section{Keywords:}

Pulp mill sludge

Land application

GIS

Suitability maps

\begin{abstract}
A B S T R A C T
Pulp mill sludge produced in the Cova da Beira region (Portugal) contains organic matter (11-47\%), nitrogen (38-2560 $\mathrm{mg} \mathrm{N} / \mathrm{kg}$ ) and phosphorus (167-370 $\mathrm{mg} \mathrm{P} / \mathrm{kg}$ ), which may be valuable for increasing soil productivity. The levels of heavy metals are below the limits recommended by legislation and the amount of nitrogen and phosphorous to be introduced in soils does not present a risk for nutrient leaching. After identifying the environmental and technical restrictions on its application, an area of 1650 ha was identified where the sludge can be applied in forage crops, fruit trees, olive groves and vineyards. A suitable area was also found for a biosolids storage centre. The use of GIS allowed to define a sludge application index and to produce land-use suitability maps, which can be useful for sludge management.
\end{abstract}

(c) 2010 Elsevier B.V. All rights reserved.

\section{Introduction}

The Cova da Beira region is located in the interior centre of Portugal and is influenced by the moderate Mediterranean climate. It has an area of $1375 \mathrm{~km}^{2}$, the annual average temperature is $14.5^{\circ} \mathrm{C}$ and the average rainfall is $820 \mathrm{~mm}$. The majority of the soil in this region has low organic matter content (Ribeiro, 2000; LQARS, 2000), which could be a disadvantage for its use, taking into account the agricultural productivity expected under the Irrigation Cova da Beira Irrigation System and the maintenance of tourism projects (e.g. golf fields).

Organic matter plays a very important role in soil conservation, due to the beneficial effect it has on its physical, chemical and biological properties, and protection against some forms of pollution and degradation. Some types of organic waste generated in urban areas and industries, including municipal solid waste and sludge from wastewater treatment plants (WWTP), may after treatment be a source of organic matter and nutrients (e.g. nitrogen, phosphorus and calcium) to incorporate in poor soils or under fast degradation processes.

Pulp mill sludge from the paper industry seems to have contents of both organic matter and nutrients (Nkana et al., 1999; Foley and Cooperband, 2002; Jordan and Rodriguez, 2004) which may be considered suitable for organic and nutrient correction of poor soil such as that covered by the Cova da Beira Irrigation System. This kind of application, besides improving soil fertility and waste reuse, may reduce treatment and disposal costs.

\footnotetext{
* Corresponding author. Tel.: +351 275 329981; fax: +351 275329969.

E-mail address: ajca@ubi.pt (A. Albuquerque).
}

However, the use of organic residues in soil requires good application practices and periodic monitoring of the quality of the soils, residues and water resources near the application area. The presence of phosphorus and nitrogen compounds, heavy metals, refractory organic compounds and pathogenic agents may pose a risk to water quality (e.g. risk of eutrophication and groundwater contamination) and soil (e.g. toxicity of soils and plants) and public health. Restrictions on sludge application, based on its nutrient content and plant needs, are less rigorous but the recycling practice must ensure no conflicts with good agricultural practices set in codes and guides of good agriculture practices, both at national (MADRP, 1997; MADRP, 2000) and international (EPA, 1994; ESD, 1999; DELG, 2008a) levels.

The application of pulp mill sludge (produced during the treatment of effluents from pulp and paper industry) should therefore be treated with caution and according to safety regulations as presented in Jordan and Rodriguez (2004) and IFC (2007). In Europe, this practice is subject to regulation by the European Community through Directives 86/278/EEC (Sewage Sludge Directive) and 91/692/EEC (Standardizing and Rationalizing Reports on the Implementation of Certain Directives Relating to the Environment), namely in terms of annual maximum permitted application rates and annual maximum concentrations of metals and nutrients to be incorporated in soils. These acts seek to discipline and supervise the use of waste through regulations which ensure that its use does not contribute to soil contamination by heavy metals or to diffuse sources of pollution, especially for nitrogen compounds (Directive 91/676/EEC - Nitrates Directive). The legal framework sets application limits (Directive 86/278/EEC and Portuguese Decree-Law No. 118/06 - Agricultural Application of Sludge), according to the characteristics identified for waste, soils and spatial limitations. 
Celtejo's plant (Vila Velha de Ródão, Portugal) produces around 1200 ton/year of dewatered primary sludge and 5000 ton/year of dewatered secondary sludge. Since the costs associated with its treatment, transportation and final disposal have risen significantly in the last years, mainly due to landfill limitations introduced by Directive 99/31/EC (a reduction to $35 \%$ of the total biodegradable waste going to landfills must be achieved by 2016 in order to reduce carbon dioxide and methane emissions), the company has considered several alternative solutions for the residues, namely land spreading in Cova da Beira soils. This option may represent a natural reuse and recycling of waste and it can be a cost-effective solution, by reducing the dependence on landfilling while minimizing negative environmental impacts and it is a practice recommended by authors such as O'Brien et al. (2003) and Ochoa de Alda (2008). Due to the considerable distance between the source of sludge production (Celtejo's plant) and the potential application areas (agricultural fields in the Block of Covilhã, covered by the Cova da Beira Irrigation System), the location of a centre for biosolids storage will be important to allow for a better control of its application.

The definition of a methodology for sludge application on agricultural land requires the collection, processing and analysis of complex information (e.g. land use, environmental and legal restrictions, characteristics of the sludge and agricultural practices, and road accesses). The use of Geographic Information Systems (GIS) allows the georeferencing, organization, processing and analysis of such complex information, as well as the creation of a database for sludge application management. GIS tools may also be used to study a location for sludge storage.

The main objective of this work was to evaluate the potential agricultural area in the Block of Covilhã (covered by the Cova da Beira Irrigation System) for land application of the pulp mill sludge annually produced at the Celtejo plant. GIS tools were used for this purpose, as well as for selecting an area for a biosolids storage centre.

\section{Materials and methods}

The study included the following four main stages:

1. Pulp mill sludge characterization.

2. Definition and characterization of the study area.

3. Identification of the agricultural areas with potential sludge application.

4. Location of an area for a biosolids storage centre.

The first stage included the characterization of the industry, the production process, the type of waste generated, the WWTP and the pulp mill sludge (primary and secondary). The main study sources were the materials provided by Celtejo Ltd., including publications and reports on their activities and physical and chemical data from the sludge characterization, complemented with visits to the plant.

The second stage included the identification and evaluation of the agricultural areas with potential for receiving sludge, taking into account several constraints (e.g. areas having both a protection status and technical restrictions such as water resources, urban areas and high-slope areas). The study was confined to the Block of Covilhã and made use of several and varied information in digital form, including:

- Extract of Portuguese Military Maps No. 235 and No. 236 (1/25000 scale, raster).

- Map of the Perimeter Irrigation Block of Covilhã (1/25000 scale, vector).

- Extract of the National Agricultural Reserve for the civil parishes of Ferro, Peraboa and Caria (1/25000 scale, raster).
- Extract of the National Natural Reserve for the civil parishes of Ferro, Peraboa and Caria (1/25000 scale, raster).

- Altimetry data (1/25000 scale, vector).

- Orthophotomaps (photogrammetric flights of 2002, 2003 and 2004; $1 / 5000$ scale, raster).

In the third stage, several agricultural areas, suitable for sludge application, were selected. The elements with technical restrictions were located and georeferred (e.g. hydrographic network, water transport pipelines, water supply and water irrigation systems, areas for biological agriculture, roads, urban housing areas, isolated residential areas and land slopes), including as well the collection and interpretation of data on soil characteristics collected from 57 agricultural parcels.

Based on the collected information, some of which was confirmed in field visits, the following tasks were developed:

- Conversion of some information from analogue to digital form.

- Editing and processing of digital information.

- Construction of a geographic model.

- Construction of new thematic maps.

- Spatial analysis of the thematic maps.

- Structuring of alphanumeric and cartographic information.

- Construction of a database.

The fourth stage involved studying the location for a biosolids storage centre in a strategic point, which must allow the optimization of its distribution through the agricultural parcels identified in the third stage. The search for a location was carried out after producing a suitability map, generated from eight thematic maps (National Agricultural Reserve (RAN), National Ecological Reserve (REN), biological agriculture (organic agriculture), urban perimeter, raw water supply sources, water streams network, roads and slopes), which were developed in the third stage. A suitability index was developed for that purpose.

The information analysis was carried out using the software ArcGIS 9.1 (ESRI, USA) and the ArcCatalog and ArcMap applications, namely for the following main tasks:

- Integration and management of spatial and non-spatial data (Raster or Vector).

- Editing of both data and geographical entities.

- Overlaying thematic information topics.

- Spatial analysis (Spatial Analyst).

- Design of slope maps (3D Analyst).

- Definition of a protection zone on the border of a geographical entity, using the buffer application.

- Query of databases according to predefined criteria.

- Georeferring of elements or entities.

- Geoprocessing of the information for mapping information in the selected study area.

- Determination of the locations with higher suitability for a biosolids centre using map algebra (Raster Calculator).

Based on the information and cartography collected in either raster or vector format the following tasks were carried out:

(1) Survey of agricultural areas with potential for pulp mill sludge application.

(2) Establishment of a suitability map for reuse of pulp mill sludge.

(3) Selection of a location for biosolids storage.

(4) Development of a database for the selected agricultural parcels, assuming the biosolids storage centre as the epicentre for sludge distribution. 
Table 1

Pulp mill sludge characteristics from the primary and secondary treatment.

\begin{tabular}{|c|c|c|c|}
\hline Parameters & Primary sludge & Secondary sludge & Maximum permissible value ${ }^{a}$ \\
\hline Dry matter (DM, \%) & 25 & 10 & - \\
\hline Organic matter (OM, \%) & 47 & 11 & - \\
\hline $\mathrm{pH}$ & 7.2 & 7.8 & - \\
\hline Total nitrogen $(\mathrm{TN}, \mathrm{mg} / \mathrm{kg})$ & 38 & 2560 & - \\
\hline Ammonia nitrogen $\left(\mathrm{NH}_{4}-\mathrm{N}, \mathrm{mg} / \mathrm{kg}\right)$ & 4 & 1090 & - \\
\hline Phosphorus (P, mg/kg) & 167 & 370 & - \\
\hline Cadmium (Cd, mg/kg) & 1.4 & 0.34 & 20 \\
\hline Copper $(\mathrm{Cu}, \mathrm{mg} / \mathrm{kg})$ & 13.0 & 2.8 & 1000 \\
\hline Nickel (Ni, mg/kg) & 10.5 & 1.44 & 300 \\
\hline Lead $(\mathrm{Pb}, \mathrm{mg} / \mathrm{kg})$ & 13.2 & 1.1 & 750 \\
\hline Zinc (Zn, mg/kg) & 83.0 & 12.9 & 2500 \\
\hline Chromium (Cr, mg/kg) & 19.0 & 1.9 & 1000 \\
\hline
\end{tabular}

a According to the Directive 86/278/EEC and the Portuguese Decree-Law 118/06.

\section{Results and discussion}

\subsection{Pulp mill sludge characterization}

The WWTP of Celtejo Ltd. includes primary treatment with sedimentation tanks and secondary treatment with activated sludge tanks (described in Ribeiro, 2008), resulting in primary sludge (about 3.5 ton/day) and secondary sludge (about 14 ton/day), both of which have mechanical dehydration through centrifugation. Table 1 presents a characterization of each type of sludge according to the analysis carried out in Celtejo Ltd., as well as the limits of heavy metals acceptable for soil application.

The $\mathrm{pH}$ of both sludge is proper for land application since the limit set in several manuals and codes of good practice is 5 (EPA, 1994; EPA, 1997; ESD, 1999; MADRP, 1997; MADRP, 2000; DELG, $2008 \mathrm{~b})$. On the other hand, the $\mathrm{pH}$ of soils detected in the 57 agricultural parcels ranged from 4.5 to 6.6 , which means that most of the soils of that region are acid (according to the classification presented in EPA, 1994; LQARS, 2000; DELG, 2008b). Therefore, the addition of pulp mill sludge would contribute to increase the $\mathrm{pH}$ of those soils.

The primary sludge presents contents of both organic matter and dry matter higher than the secondary one, because it is less mineralized. It also has a higher content of heavy metals, which should be associated with its adsorption on sedimentation solids. The secondary sludge (biological sludge) has organic matter content lower than the primary one because it is more mineralized. However, the concentrations of nitrogen and phosphorus are higher due to the high nutrient removal efficiency provided by the activated sludge process.

The organic matter content detected in the primary sludge is, however, lower than the values presented in other Portuguese studies, varying between $80 \%$ and $87 \%$ according to Ribeiro (2000) and Nunes and Cabral (2000). The secondary sludge also presents values of organic matter lower than the ones detected in other studies (between 49\% and 89\% according to Nkana et al., 1999 and Nunes and Cabral, 2000). In the latter, besides the organic matter removal being higher in the secondary treatment (in the liquid phase), the sludge organic content is low due to the subsequent mineralization during sludge storage and treatment. Nevertheless, the organic matter content found in both sludge may benefit the soils of the Cova da Beira region since values below $1 \%$ were detected in all the 57 agricultural parcels.

Nutrients (nitrogen and phosphorus) in both types of sludge present lower concentrations when compared to the values indicated by several authors (Nkana et al., 1999; Nunes and Cabral, 2000; Foley and Cooperband, 2002; Curnoe et al., 2006; Shipitalo and Bonta, 2008), who pointed to values over $650 \mathrm{mg} \mathrm{TP} / \mathrm{kg}$, $5000 \mathrm{mg} \mathrm{NH}_{4}-\mathrm{N} / \mathrm{kg}$ and over $10,000 \mathrm{mg} \mathrm{TN} / \mathrm{kg}$. However, they are still appropriate to be used in soils for fertilizer purposes, especially the secondary sludge.

The concentrations of heavy metals in both types of sludge are below the limits allowed by the 86/278/EEC Directive, and by national and international guides (EPA, 1994; EPA, 1997; MADRP, 1997; DELG, 2008a). High concentrations are not expected in soil after sludge incorporation. The values are also lower than the ones found by Lacorte et al. (2003) except for Cd, but higher than the ones reported by O'Brien et al. (2003). Therefore, as also reported by Cabral et al. (2008), metals do not seem to be a limiting factor for sludge application to land.

Therefore, it seems reasonable to assume that the sludge produced at Celtejo may be applied as soil fertilizer, soil organic corrective, acidity corrective or source of nutrients for plants. Shipitalo and Bonta (2008) have observed that paper mill sludge can improve reclamation of surface-coal mines where low $\mathrm{pH}$ and organic-carbon levels in the spoil cover material can inhibit revegetation.

\subsection{Definition and characterization of the study area}

The area selected to carry out the study corresponds to the Block of Covilhã, covered by the Irrigation Plan of Cova da Beira, located in the South side of the "Serra da Estrela" mountain, a lowered area, where altitudes range between 400 and $500 \mathrm{~m}$.

The Block of Covilhã was delimited from the digitalisation of the Military Maps No. 235 and 236 and the georeferencing of recent structures (e.g. A23 motorway and new residential areas), having been necessary to overlap cartographic elements. The total area assessed was 1616 ha (Fig. 1).

\subsection{Identification of the agricultural areas suitable for sludge application}

The first step included the identification of the agricultural areas with deep soils classified as classes A and B according to the Portuguese Decree-Law No. 73/2009 (Agricultural Reserve) and to the World Reference Base for Soil Resources Deckers et al. (1998), which belong to the RAN as shown in Fig. 1 .

The second step included the identification and delimitation of areas with spatial restrictions according to the Portuguese DecreeLaw No. 118/06, the Directive 86/278/EEC and to suggestions from several guides and codes of good agricultural practices (EPA, 1994, 1997; USDA-SCS, 1994; ESD, 1999; MADRP, 1997; DELG, 2008a), namely the ones located at least:

- $50 \mathrm{~m}$ away from water sources for irrigation;

- $100 \mathrm{~m}$ away from water supply sources for human consumption;

- $200 \mathrm{~m}$ away from urban residential areas; 


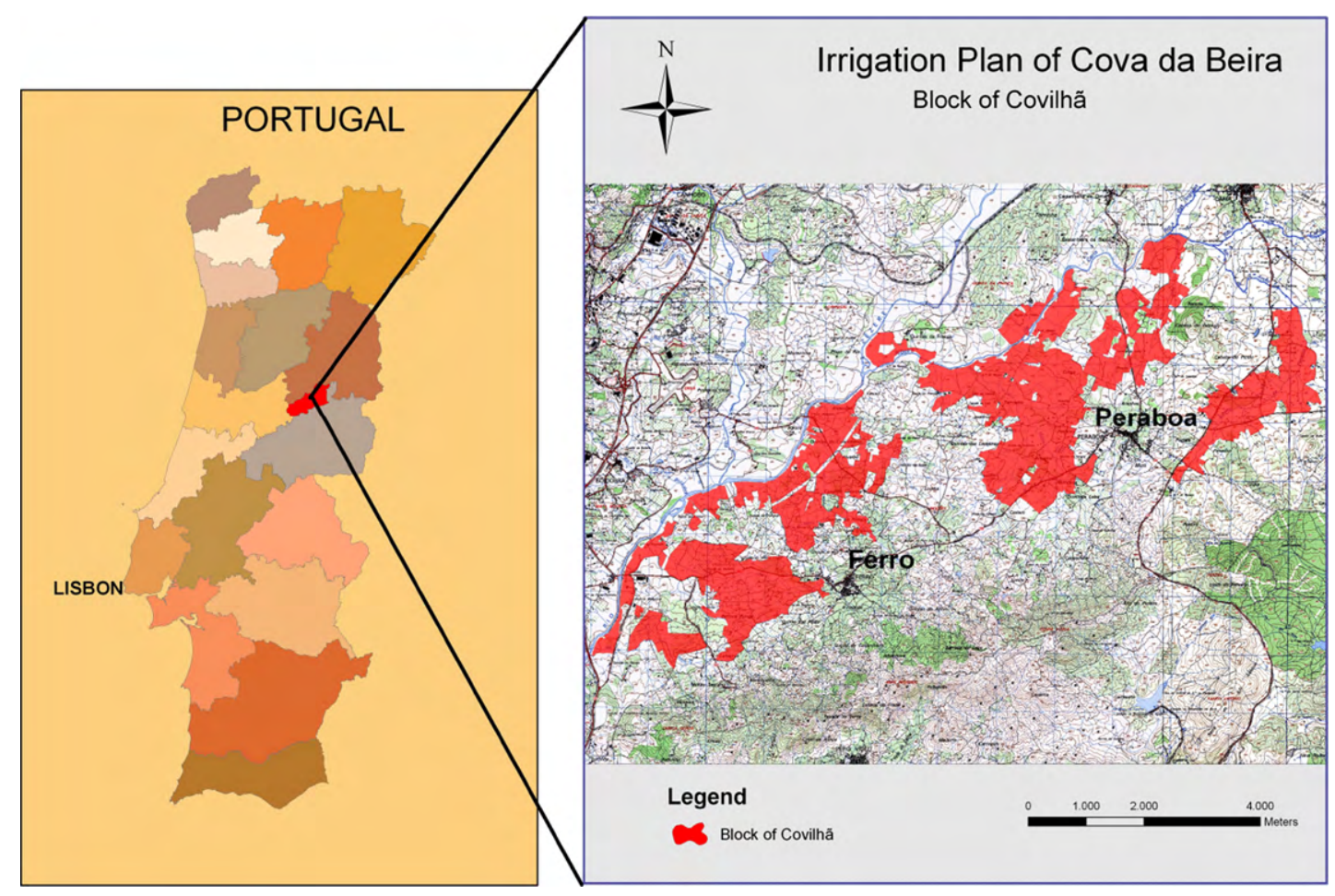

Fig. 1. Location of the Block of Covilhã (Cova da Beira Irrigation System).

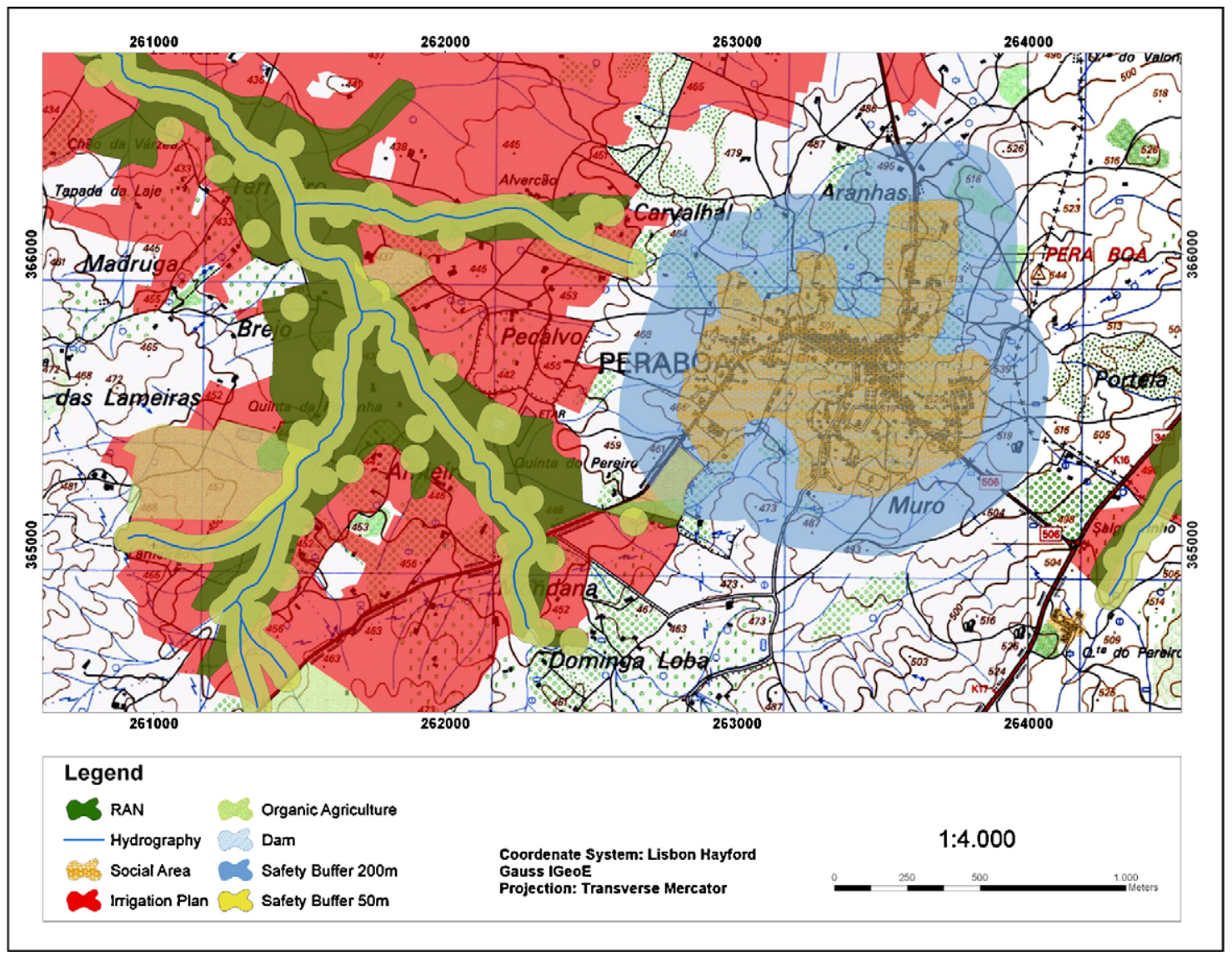

Fig. 2. Buffer areas for $50 \mathrm{~m}$ and $200 \mathrm{~m}$. 


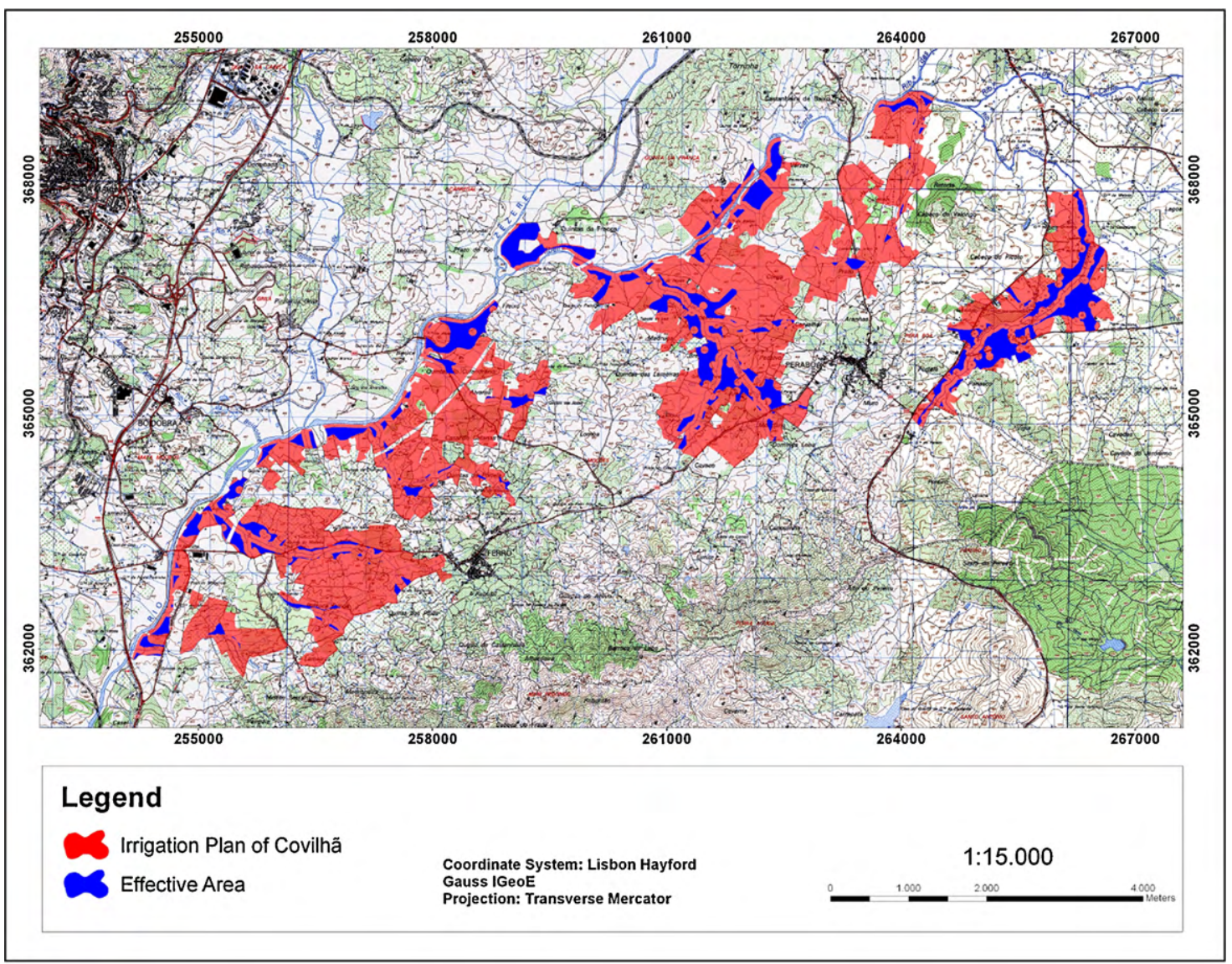

Fig. 3. Suitability map for pulp mill sludge application.

- $30 \mathrm{~m}$ away from borders of navigable waters;

- $10 \mathrm{~m}$ away from borders of non-navigable waters.

The areas for biological agriculture were also skipped since sludge application is not permitted in soils with such activity as referred in the Council Regulation (EEC) No. 2092/91 (Organic Production of Agricultural Products).

The third step included the definition of two buffer zones: $50 \mathrm{~m}$ for water sources (streams, wells, lakes and dams) and $200 \mathrm{~m}$ for residential areas in order to allow the protection of these areas against contamination and odours (Fig. 2).

The delimitation of all the restrictions resulted in a total suitable area (without restrictions) of 253 ha (Fig. 3) for pulp mill sludge application, which represents $15.7 \%$ of the total area of the Block of Covilhã. In order to evaluate if this available area was enough for the total application of the sludge produced at Celtejo (6200 ton/year), a frequency of land application was established. The suitability of the crops and agricultural parcels for sludge application was then evaluated.

The allowed dry sludge application rate was 6 ton/(hayear) (limit value defined in the Directive 86/278/EEC and used by most Member States of UE as reported in IEEP, 2009). Higher values could be used as long as the amounts of heavy metals incorporated into the soil do not exceed the limit values shown in Table 1. Considering the typical dry matter percentages for this kind of sludge (25\% for primary sludge, $10 \%$ for secondary sludge), the annual available quantity of sludge in dry matter is 800 ton (details on calculations are presented in Ribeiro, 2008).

Taking into account that most of the agricultural parcels present a moderate land slope and the information from the Portuguese Guide for Good Agricultural Practices (MADRP, 1997) on the pre- vention of both leaching risk and surface runoff associated to organic waste application, a single annual application was considered. Therefore, the area required to apply all the sludge annually produced at Celtejo is approximately 133 ha, $52.6 \%$ of the available area. As the company intends to increase production, the suitable area available in the Block of Covilhã may absorb up to 11677 ton/year of pulp mill sludge (considering an average percentage of dry matter of $13 \%$ ).

The loads of $\mathrm{Cd}, \mathrm{Cr}, \mathrm{Ni}, \mathrm{Pb}, \mathrm{Zn}$ and $\mathrm{Cr}$, which could be introduced in the soil after sludge application, are presented in Table 2 and were calculated considering a dry sludge application rate of 6 ton/(ha year) and the concentration of heavy metals in the sludge (Table 1) following Eq. (1).

$M=L S \cdot C$

where $M$ is the load of metals to be introduced in soil ( $\mathrm{kg} /($ ha year)), $L S$ the load of dry sludge to be applied ( $\mathrm{kg} /$ (ha year)) and $C$ is the concentration of heavy metal in the sludge $(\mathrm{kg} / \mathrm{kg})$.

As shown in Table 2, the quantities of heavy metals either in both types of sludge or to be introduced in the soil are much lower than the limits defined in both the Directive 86/278/EEC and the Portuguese Decree-Law No. 118/06. The values are still lower than the more restrictive goals set by the Irish Code of Good Practice for the Use of Biosolids in Agriculture (DELG, 2008a). Therefore, it may reasonable to assume that a dry sludge application rate higher than 6 ton/(ha year) can be used in the soils of the Block of Covilhã. ESD (1999) suggests application rates of pulp mill sludge up to 12.5 ton/(ha year). However, the risks for leaching and surface runoff should be previously evaluated. Even when considering more restricted limits for pulp mill sludge application in agriculture, such as those presented in the Canadian regulation $(3 \mathrm{mg}$ 
Table 2

Amount of heavy metals associated to pulp mill sludge produced at Celtejo.

\begin{tabular}{|c|c|c|c|c|c|c|}
\hline \multirow[t]{2}{*}{ Parameters } & \multicolumn{6}{|c|}{ Heavy metals } \\
\hline & $\mathrm{Cd}$ & $\mathrm{Cu}$ & $\mathrm{Ni}$ & $\mathrm{Pb}$ & $\mathrm{Zn}$ & $\mathrm{Cr}$ \\
\hline Amount in the primary sludge $(\mathrm{mg} / \mathrm{kg})$ & 1.4 & 13 & 10.5 & 13.2 & 83 & 19 \\
\hline Amount in the secondary sludge (mg/kg) & 0.34 & 2.8 & 1.5 & 1.1 & 12.9 & 1.9 \\
\hline Amount to be incorporated in soils $(\mathrm{kg} /($ ha year $))$ by the primary sludge $\mathrm{a}^{\mathrm{a}}$ & 0.008 & 0.08 & 0.06 & 0.08 & 0.5 & 0.15 \\
\hline Amount to be incorporated in soil ( $\mathrm{kg} /($ ha year $))$ by the secondary sludge $\mathrm{a}^{\mathrm{a}}$ & 0.002 & 0.017 & 0.009 & 0.007 & 0.080 & 0.011 \\
\hline Limit values for amounts that may be added to agricultural soils $(\mathrm{kg} /(\text { ha year }))^{\mathrm{b}}$ & 0.15 & 12 & 3 & 15 & 30 & 4.5 \\
\hline Limit values in sludge for use in agriculture $(\mathrm{mg} / \mathrm{kg})^{\mathrm{b}}$ & 20 & 1000 & 300 & 750 & 2500 & 1000 \\
\hline
\end{tabular}

a For an application rate of 6 ton/(ha year).

b Directive 86/278/EEC and Portuguese Decree-Law 118/06.

$\mathrm{Cd} / \mathrm{kg}, 100 \mathrm{mg} \mathrm{Cu} / \mathrm{kg}, 62 \mathrm{mg} \mathrm{Ni} / \mathrm{kg}, 150 \mathrm{mg} \mathrm{Pb} / \mathrm{kg}, 500 \mathrm{mg} \mathrm{Zn} / \mathrm{kg}$ and $210 \mathrm{mg} \mathrm{Cr} / \mathrm{kg}$; ESD, 1999), the values of Table 2 are still lower.

Organic $\mathrm{N}$ is also of concern since it converts (mineralizes) into plant-available inorganic forms (ammonia nitrogen $\left(\mathrm{NH}_{4}-\mathrm{N}\right)$ and nitrate nitrogen $\left(\mathrm{NO}_{3}-\mathrm{N}\right)$ ). $\mathrm{N}$ availability during the year of application depends on the $\mathrm{N}$ form. $\mathrm{NH}_{4}-\mathrm{N}$ and $\mathrm{NO}_{3}-\mathrm{N}$ are readily available for plant uptake. However, if the sludge is applied on the soil surface and not quickly incorporated, considerable $\mathrm{NH}_{4}-\mathrm{N}$ may be lost to the air as ammonia gas (volatilization). The excess of ammonia not volatilized may therefore be oxidized to nitrate through nitrification, which may be subject to leaching loss. Nitrate is known to be a precursor of negative environmental impacts (e.g. water stream eutrophication) and public health problems (e.g. methemoglobinemia and gastric cancer), and therefore it must be controlled.

The amount of $\mathrm{N}$ accumulated in soil depends on the plant uptake and the type of culture to be used. In general, about $10-50 \%$ of the organic $\mathrm{N}$ may become available in the year of application, $5-20 \%$ will be available in the second year and smaller amounts will be available in subsequent years (EPA, 1997; MADRP, 2000; DELG, 2008a). According to Portuguese and international guides for good agricultural practices (MADRP, 1997, 2000; DELG, 2008a,b) the application rate of total $\mathrm{N}$ should not exceed $210 \mathrm{~kg} \mathrm{~N} /$ (ha year) in any sensitive areas and $170 \mathrm{~kg} \mathrm{~N} /$ (ha year) in areas sensitive to nitrate leaching according to the Directive 91/676/EEC (Nitrates Directive).

Phosphorus is found in most soils as mineral forms, which tend to be retained by mineral colloids or to form phosphates (calcium phosphates, aluminum and iron) with low solubility. The use of pulp mill sludge may improve the content of assimilative phosphorus (Nunes and Cabral, 2000; LQARS, 2000). The research carried out in Portugal has observed that the application of an average rate of approximately $75 \mathrm{~kg} \mathrm{P}_{2} \mathrm{O}_{5}$ /(ha year) is enough to increase by $10 \mathrm{mg} / \mathrm{kg}$ the content of assimilative P in soil (LQARS, 2000).

Table 3 presents the loads of nitrogen and phosphorus to be introduced in the soil for the two types of sludge considering a dry sludge application rate of 6 ton/(ha year).

Results show that the amount of nitrogen to be introduced in the soils of the study area $(15.6 \mathrm{~kg} /$ (ha year)) is much lower than the limits recommended by Portuguese and international guides
(MADRP, 2000; DELG, 2008a,b) even for areas sensitive to nitrate leaching. Therefore, it seems reasonable to assume that sludge application rates higher than 6 ton/(ha year) can be applied if the amount of $\mathrm{N}$ in soil does not exceed $210 \mathrm{~kg} \mathrm{~N} /$ (ha year) and if both the quality of water sources and the risk of nitrate percolation in the soil were properly assessed. Limited data shows that EPA drinking water standards were not exceeded with paper mill sludge application rates having total $\mathrm{N}$ equivalents of less than $300 \mathrm{~kg} /$ (ha year) (Shields et al., 1986; Kraske and Fernandez, 1993). If high C/N ratios are applied, $\mathrm{N}$ equivalent application rates for paper mill sludge can likely be higher because $\mathrm{N}$ is immobilized.

The $\mathrm{C} / \mathrm{N}$ ratio may be adjusted to avoid depressed $\mathrm{N}$ uptake through sludge application before planting. This practice will allow sufficient time for $\mathrm{N}$ mineralization to occur (Cabral et al., 1998). If immediate planting is desired, additional $\mathrm{N}$ inputs (biosolids or fertilizer) would help the microorganisms to break down the pulp residual without reducing $\mathrm{N}$ availability.

The amount of phosphorus to be incorporated in the soils is much lower ( $3.2 \mathrm{~kg} /($ ha year)) than the recommended values, used as reference by some Phosphorus Index for assessing the vulnerability of a land (USDA-SCS, 1994; McFarland et al., 1998), and therefore may be classified of very low risk for phosphorus movement. That value is still compatible with the requirement of DELG (2008b), which sets up a maximum farm phosphorus balance of no more than $10 \mathrm{~kg} \mathrm{P} /($ ha year). Therefore, sludge application rates higher than 6 ton/(ha year) can be applied if the amount of $P$ in soil does not exceed $157 \mathrm{~kg} \mathrm{P} /$ (ha year).

\subsubsection{Sludge application opportunities}

The agricultural parcels have several types of crops, which may present different susceptibility to pulp mill sludge application. The criteria for selecting the types of crops with suitability for sludge application was based on the restrictions presented in the Directive 86/278/EEC, Decree-Law No. 118/06 and Portuguese Standard NP 4434:2005 (Reuse of wastewater in irrigation; IPQ, 2005), including:

(1) Total restriction on grassland or forage crops that are used for cattle feeding.

Table 3

Amount of nitrogen and phosphorus associated to pulp mill sludge produced at Celtejo.

\begin{tabular}{|c|c|c|}
\hline Parameters & Total nitrogen & Total phosphorus \\
\hline Amount in the primary sludge $(\mathrm{mg} / \mathrm{kg})$ & 38 & 167 \\
\hline Amount in the secondary sludge ( $\mathrm{mg} / \mathrm{kg}$ ) & 2560 & 370 \\
\hline Amount to be incorporated in soils by primary sludge $(\mathrm{kg} /(\text { ha year }))^{\mathrm{a}}$ & 0.23 & 1 \\
\hline Amount to be incorporated in soil by secondary sludge $(\mathrm{kg} /(\text { ha year }))^{\mathrm{a}}$ & 15.40 & 2.2 \\
\hline Recommended limit value to be incorporated in agricultural soils in no sensitive areas ( $\mathrm{kg} /($ ha year)) & $210^{\mathrm{b}}$ & $157^{\mathrm{c}}$ \\
\hline Recommended limit value to be incorporated in agricultural soils in sensitive areas (kg/(ha year)) & $170^{\mathrm{b}}$ & - \\
\hline
\end{tabular}

a For an application rate of 6 ton/(ha year)

b DELG (2008a,b), MADRP (2000).

c USDA-SCS (1994), McFarland et al. (1998). 


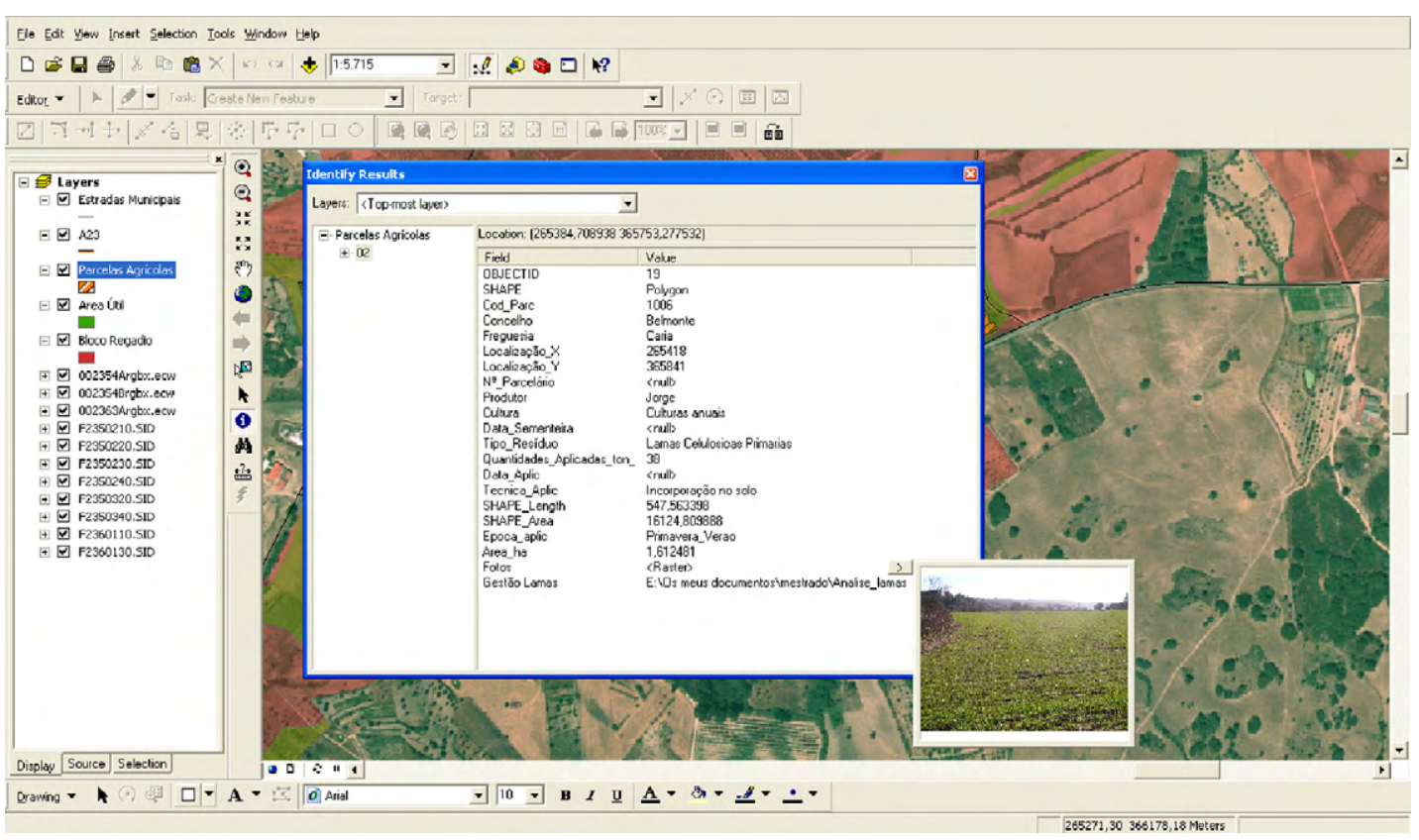

Fig. 4. Information associated to agricultural parcels.

(2) Total restriction on vegetable crops and fruit crops with direct contact during the growing period.

(3) Total restriction on soils for vegetable or fruit cultures with direct contact, for a period of 10 months before the harvest.

The accumulation of heavy metals present in sludge occurs more rapidly in vegetables than in extensive cereal crops. Therefore, the agricultural parcels selected for receiving pulp mill sludge were: annual crops (fodder and cereal crops) and grassland not used for livestock feeding, fruit crops, olive groves and vineyards.

The overlay between the suitability map for pulp mill sludge application and the respective orthophotomaps resulted in a map with all the selected agricultural parcels. A database was created with information for sludge application management in each agricultural parcel, namely the parcel code, location and parcel coordinates, parcel photo, property-owner, type of culture, soil characteristics, characteristics of sludge already applied, fertilization plan, maximum amount of applied sludge, date of application and history of applications (Fig. 4).

Although the total suitable area evaluated in the Block of Covilhã is sufficient for the total application of the sludge produced at Celtejo, at parcel level it is necessary to guarantee its safe application in proper conditions. Periodical data updating for each parcel is needed for that purpose, namely the type of culture or crops and the soil characteristics.

Besides allowing the introduction of new agricultural parcel data and the modification of existing parcel data, the database created allows the online consultation of historical data through remote access.

These records perform a useful management tool, since they enable the management and control of agricultural parcel activities (for example, the risk of excessive accumulation of heavy metals and nutrients may be avoided by consulting historical data and by defining rotation procedures).

\subsection{Localization of sludge storage centre}

A GIS in raster format was used to create the suitability map and the results were processed according to the algebra of maps (maps overlapping for the different variables). A weighted linear
Table 4

Weights attributed to each variable.

\begin{tabular}{|c|c|c|c|}
\hline Criteria & Map & Description & $P$ \\
\hline Environmental & RAN & $\begin{array}{l}\text { Area with RAN } \\
\text { Area without RAN }\end{array}$ & $\begin{array}{l}0 \\
1\end{array}$ \\
\hline Environmental & REN & $\begin{array}{l}\text { Area with REN } \\
\text { Area without REN }\end{array}$ & $\begin{array}{l}0 \\
1\end{array}$ \\
\hline Technical & BA & $\begin{array}{l}\text { Area with biological agriculture } \\
\text { Area without biological agriculture }\end{array}$ & $\begin{array}{l}0 \\
1\end{array}$ \\
\hline Technical & UPa & $\begin{array}{l}200 \mathrm{~m} \text { from urban areas } \\
200-300 \mathrm{~m} \text { from urban areas } \\
300-400 \mathrm{~m} \text { from urban areas } \\
400-500 \mathrm{~m} \text { from urban areas } \\
500-600 \mathrm{~m} \text { from urban areas } \\
\text { Over } 600 \mathrm{~m} \text { from urban areas }\end{array}$ & $\begin{array}{l}0 \\
1 \\
2 \\
3 \\
4 \\
5\end{array}$ \\
\hline Environmental & WA & $\begin{array}{l}50 \mathrm{~m} \text { from water abstraction sources } \\
50-100 \mathrm{~m} \text { from water abstraction sources } \\
100-200 \mathrm{~m} \text { from water abstraction sources } \\
200-300 \mathrm{~m} \text { from water abstraction sources } \\
300-400 \mathrm{~m} \text { from water abstraction sources } \\
\text { Over } 500 \mathrm{~m} \text { from water abstraction sources }\end{array}$ & $\begin{array}{l}0 \\
1 \\
2 \\
3 \\
4 \\
5\end{array}$ \\
\hline Environmental & WS & $\begin{array}{l}50 \mathrm{~m} \text { from water streams } \\
50-100 \mathrm{~m} \text { from water streams } \\
100-200 \mathrm{~m} \text { from water streams } \\
200-300 \mathrm{~m} \text { from water streams } \\
300-400 \mathrm{~m} \text { from water streams } \\
\text { Over } 500 \mathrm{~m} \text { from water streams }\end{array}$ & $\begin{array}{l}0 \\
1 \\
2 \\
3 \\
4 \\
5\end{array}$ \\
\hline Technical & $\mathrm{R}$ & $\begin{array}{l}\text { Over } 200 \mathrm{~m} \text { from roads } \\
150-200 \mathrm{~m} \text { from roads } \\
100-150 \mathrm{~m} \text { from roads } \\
50-100 \mathrm{~m} \text { from roads } \\
\text { Less than } 50 \mathrm{~m} \text { from roads }\end{array}$ & $\begin{array}{l}1 \\
2 \\
3 \\
4 \\
5\end{array}$ \\
\hline Technical & $\mathrm{S}$ & $\begin{array}{l}\text { Over } 10 \% \\
8-10 \% \\
6-8 \% \\
4-6 \% \\
2-4 \% \\
0-2 \%\end{array}$ & $\begin{array}{l}0 \\
1 \\
2 \\
3 \\
4 \\
5\end{array}$ \\
\hline
\end{tabular}

a The range of values and weights were defined according to the location of houses or equipments. 


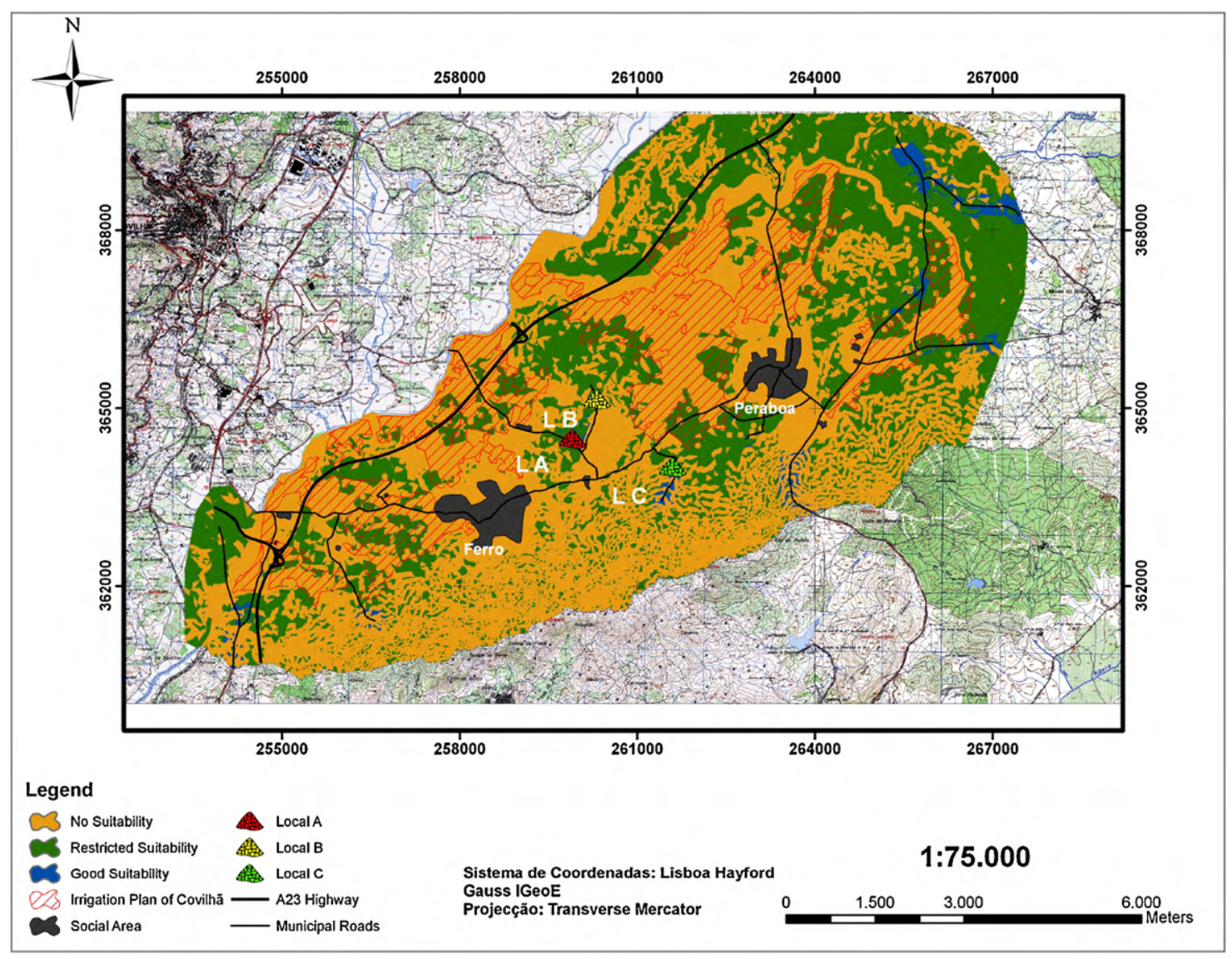

Fig. 5. Suitability map for the sludge storage centre location.

combination model was used for delineating and ranking suitable sites for sludge storage. After the exclusion of restrictive areas, the available area was divided into cells of $100 \mathrm{~m}^{2}$, each constituting an alternative for the centre location. For producing the suitability map eight thematic maps ("RAN", "REN", "biological agriculture (BA)", "urban perimeter (UP)", "water abstraction sources (WA)", "water streams (WS)", "roads (R)" and "slopes (S)") were used. A similar approach was used by Basnet et al. (2001) for land application of animal waste, by Zhao et al. (2009) to locate wastewater treatment in areas with several environmental restrictions and by Kallali et al. (2007) to select sites for groundwater recharge in the North East of Tunisia.

The inclusion of the thematic maps WA, WS and S is important for the site selection process in order to minimize the leaching of nutrients lost from the storage centre to water resources. The UP map will minimize the presence of odours and risks for public health, whilst the R map is important for searching places that can satisfy the transport of sludge to all agricultural parcels.

The computation procedure involved the overlap between the exclusion areas of each of the eight thematic maps and the suitable areas for pulp mill sludge application (Fig. 3) through algebraic operations of maps as presented in Eq. (2). A Suitability Index for Biosolids Centre storage (ISBC) was therefore developed.

$I S B C_{i}=\left(a_{i j}^{k}\right)_{m n} \times P=\sum_{k=1}^{t m}\left(\left(\begin{array}{cccc}a_{11}^{k} & a_{12}^{k} & \cdots & a_{1 n}^{k} \\ a_{21}^{k} & a_{22}^{k} & \cdots & a_{2 n}^{k} \\ \cdots & \cdots & \cdots & \cdots \\ a_{m 1}^{k} & a_{m 2}^{k} & \cdots & a_{m n}^{k}\end{array}\right) \times P^{k}\right)$ where $\left(a_{i j}^{k}\right)$ is the vector of cell values from each thematic map which is in line $i$ in row $j, m$ and $n$ are the dimensions of the thematic grid map, $k$ is the thematic map, $t m$ is the number of thematic maps and $P$ is the vector of weights associated to each thematic map.

The value of each cell of the suitability map (which corresponds to the value of $I S B C_{i}$ ) resulted from the sum of the products between the weight attributed to each thematic map (Table 4) and the value stored in each cell of each thematic map (cells with $10 \mathrm{~m} \times 10 \mathrm{~m}$ size) through algebraic operations of maps.

The Eq. (1) was therefore introduced in the Raster Calculator function for the final suitability map to be calculated as express Eq. (3), which is presented in Fig. 5.

$I S B C_{i}=\left(b_{i j}\right)_{m n}=\left(\begin{array}{cccc}b_{11} & b_{12} & \cdots & b_{1 n} \\ b_{21} & b_{22} & \cdots & b_{2 n} \\ \cdots & \cdots & \cdots & \cdots \\ b_{m 1} & b_{m 2} & \cdots & b_{m n}\end{array}\right)$

where $\left(b_{i j}\right)$ is the vector of cell values for the suitability map which is in line $i$ in row $j, m$ and $n$ are the dimensions of the suitability grid map.

The ISBC ranges between 0 and 3125 (maximum value for a combination of $p=5$ for the 5 last thematic maps, i.e. $5^{5}$ ).

Taking into account the weight considered for each variable and the combination of multiplicative factors, three suitability classes were defined for the suitability map: 0 ("without suitability for storage centre construction"), 1-1024 ("conditioned suitability for storage centre construction") and 1024-3125 ("good suitability for storage centre construction"). This procedure is similar to the ones followed by Basnet et al. (2001), for the animal waste application, 
and by Zhao et al. (2009), for the location of wastewater infrastructures.

Considering two sludge applications per year, the quantity of sludge annually produced at Celtejo and the height of the storage piles (5-10 m), an area of approximately 2.1 ha for the storage centre would be necessary (without taking into account the area for additional equipment such as a supporting building, washing equipment and a lagoon for leachate storage). After a visit to the areas classified as "good suitability for storage centre construction", three areas with enough space were identified and are shown in Fig. 5 (referred as LA, LB and LC). From these, the LA area appears to have better suitability since it has a better access.

\section{Conclusions}

The Cova da Beira region soils are, in general, acid and poor in organic matter. The intensive land exploitation designed to support agricultural, industrial and touristic activities may, if protective measures are not taken, lead to the degradation of the land. The annual amount of pulp mill sludge produced at Celtejo may, after treatment, be used in less than $50 \%$ of the available suitable agricultural land as an organic corrective, acidity corrective and as a fertilizer for agricultural crops. This practice, besides the agricultural sludge valorisation, would reduce the treatment and final destination costs and contribute for soil protection, particularly in intensive season exploitation. This practice will bring benefits to the environment and the local economy, by presenting a good level of social acceptance without needing many technical resources and by contributing to a sustainable development of the region.

The maximum amount of heavy metals and nutrients that could be introduced into the soil would not exceed the limits defined by European Directives, Portuguese Decree-Laws and national and international guides. The results allow assuming that, if necessary, an application rate higher than 6 ton/(ha year) could be considered.

The use of GIS allowed to store, manipulate, analyze and georeference complex information from soils, sludge, land use and environmental and technical restrictions. A suitability map for pulp mill sludge application was generated and a database for sludge management of each suitable agricultural parcel was created. A multicriteria analysis was carried out to identify potential sites for the location of a sludge storage centre taking into account technical, environmental and social criteria. A suitability index was generated, which allowed the production of a final suitability map and the location of alternative sites.

\section{Acknowledgements}

The authors would like to thank the support provided by the Celtejo AS industry and by José Riscado (STIG) during this study.

\section{References}

Basnet B, Apan A, Raine S. Selecting suitable sites for animal waste application using a raster GIS. Environmental Management 2001;28(4):519-31.

Cabral F, Vasconcelos E, Goss M, Cordovil C. The value, use, and environmental impacts of pulp-mill sludge additions to forest and agricultural lands in Europe. Environmental Reviews 1998;6:55-64.

Cabral F, Ribeiro H, Hilário L, Machado L, Vasconcelos E. Use of pulp mill inorganic wastes as alternative liming materials. Bioresource Technology 2008;99(17):8294-8.
Curnoe W, Irving D, Dow C, Velema G, Unc A. Effect of spring application of a paper mill soil conditioner on corn yield. Agronomy Journal 2006;98:423-9.

DELG. Codes of good practice for the use of biosolids in agriculture. Dublin, Ireland: Department of the Environment and Local Government; 2008a, 80 pp.

DELG. The code of good agricultural practice for the prevention of pollution of water, air and soil. Dublin, Ireland: Department of Agriculture and Rural Development; 2008b, 165 pp.

Deckers J, Nachtergaele F, Spaargaren O. World reference base for soil resources. World soil resources report no. 84. Rome, Italy: ISSS/ISRIC/FAO; 1998, 172 pp.

EPA. Land application of biosolids: process design manual, 1st ed. New York, USA: CRC; $1997,310 \mathrm{pp}$.

EPA. Land application of sewage sludge. Report EPA/831-B-93002b. Washington, USA: Environmental Protection Agency; 1994, 105 pp.

ESD. Standards and guidelines for the land application of mechanical pulp mill sludge to agricultural land. Edmonton, Alberta, Canada: Environmental Sciences Division, Alberta Environmental Protection; 1999, 44 pp.

Foley B, Cooperband L. Paper mill residuals and compost effects on soil carbon and physical properties. Journal of Environmental Quality 2002;31: 2086-95

IEEP. Report on the implementation of the Sewage Sludge Directive. London, UK: Institute for European Environmental Policy; May 2009, 40 pp.

IFC. Environmental, health, and safety guidelines - pulp and paper mills. Washington, USA: International Finance Corporation, World Bank Group; 2007, 341 pp.

IPQ. Portuguese standard 4434:2005. Reuse of wastewater in irrigation. Monte Caparica, Portugal: Portuguese Institute for Quality; 2005, 30 pp. [in Portuguese].

Jordan M, Rodriguez E. Effect of solid residues from the cellulose industry on plant growth. Journal of Plant Nutrition and Soil Science 2004;167:351-6.

Kallali H, Anane M, Jellali S, Tarhouni J. GIS-based multi-criteria analysis for potential wastewater aquifer recharge sites. Desalination 2007;215:111-9.

Kraske C, Fernandez I. Biogeochemical responses of a forested watershed to both clear-cut harvesting and paper mill sludge application. Journal of Environmental Quality 1993;22:776-86.

Lacorte S, Latorre A, Barcelo D, Rigol A, Malmqvist A, Welander T. Organic compounds in paper mill process waters and effluents. Trends in Analytical Chemistry 2003;22(10):725-37.

LQARS. Manual for culture fertilization. Lisbon, Portugal: Ministério da Agricultura, do Desenvolvimento Rural e das Pescas; 2000 [in Portuguese].

MADRP. Guide for good agriculture practices: protection of water streams against the nitrate pollution. Lisbon, Portugal: Ministério da Agricultura, do Desenvolvimento Rural e das Pescas; 1997,53 pp. [in Portuguese].

MADRP. Basic manual for agriculture practice - soil and water conservation. Lisbon, Portugal: Ministério da Agricultura, do Desenvolvimento Rural e das Pescas; 2000, 81 pp. [in Portuguese].

McFarland A, Hauck L, White J, DonhamW, Lemunyon J, Jones S. Nutrient management using a phosphorus risk index for manure application fields. In: Proceedings of manure management in harmony with the environment and society. Ames, USA: Soil and Water Conservation Society; 1998. p. 241-4.

Nkana J, Tack F, Verloo M. Dynamics of nutrients in tropical acid soils amended with paper pulp sludge. Waste Management and Research 1999;17:198-204.

Nunes J, Cabral F. Changes in soil composition due to the application of secondary pulp mill sludge. Vida Rural; 2000, p. 50-3 [in Portuguese].

O'Brien T, Herbert S, Barker A. Paper sludge as a soil amendment for production of corn. Communications in Soil Science and Plant Analysis 2003;34: 2229-41.

Ochoa de Alda J. Feasibility of recycling pulp and paper mill sludge in the paper and board industries. Resources, Conservation and Recycling 2008;52:965-72.

Ribeiro P. Effects of pulp mill sludge application on corn crops and fodder growth. BSc thesis in Agriculture Sciences. Castelo Branco, Portugal: Polytechnic Institute of Castelo Branco; 2000 [in Portuguese].

Ribeiro P. Study of the reuse potential of mill paper sludge in agricultural activities in the irrigation perimeter of the Cova da Beira Region (Covilha block) using GIS. MSc thesis in GIS. Covilhã, Portugal: University of Beira Interior; 2008, 150 pp. [in Portuguese].

Shields W, Huddy M, Somers S. In: Cole DW, Henry CL, Nutter WL, editors. In the forest alternative for treatment and utilization of municipal and industrial wastes. USA: University of Washington Press; 1986.

Shipitalo M, Bonta J. Impact of using paper mill sludge for surface-mine reclamation on runoff water quality and plant growth. Journal of Environmental Quality 2008;37:2351-9.

USDA-SCS. Phosphorus assessment tool. technical note, series number 1901. Forth Worth, Texas, USA: South National Technical Center, USDA-SCS; 1994.

Zhao Y, Qin Y, Chen B, Zhao X, Li Y, Yin X, et al. GIS-based optimization for the locations of sewage treatment plants and sewage outfalls - a case study of Nansha District in Guangzhou City, China. Communications in Nonlinear Science and Numerical Simulation 2009;14:1746-57. 